\title{
The Effectiveness of Traditional Games on the Development of Social Ability of Children in Kindergarten of Baiturridha Padang Pariaman
}

\author{
Serli Marlina \\ Department of Early Childhood \\ Education, Faculty of Education \\ Padang State University \\ serlimarlina@,fip.unp.ac.id
}

\author{
Rismareni Pransiska \\ Department of Early Childhood \\ Education, Faculty of Education \\ Padang State University \\ pransiskaunp2008@gmail.com
}

\begin{abstract}
This study aims to find out how big the effectiveness of traditional games on the Development of Social Capabilities of Children in Baiturridha Kindergarten Padang Pariaman. Research type is Quantitative research with experiment method. The sample of this study was determined based on Cluster Sampling. Instrument research using instrument grille. Instrument analysis by performing test validity and test reliability. Technique of collecting data by doing observation and test. Technique of data analysis using normality test, homogeneity test and hypothesis test. The result of this research shows that $t$ count $>t$ table, that is $9,037>2,073$, it can be concluded that the development of social ability of children in experimental class using traditional game is more effective than control class using modern game.
\end{abstract}

Keywords: development; effectiveness; social ability of children; traditional games

\section{INTRODUCTION}

Education and learning from one generation to the next through teaching, training and research. Education is one of the things included in human life. Because with human education can use each other things to meet the needs of life. Therefore, education should be done as early as possible from an early age. Based on Constitution Number 20 of 2003 on National Education System relating to Early Childhood Education in article 28 paragraph 1 which reads "Early Childhood Education is held for children from birth up to six years and is not a prerequisite for basic education". Furthermore, in Chapter 1, paragraph 14 is defined as Early Childhood Education is a coaching effort aimed at children from birth up to six years conducted through the provision of educational stimuli to assist growth and physical and spiritual development so that children have readiness in the course of further education.

Early childhood education is very important to do, because early childhood education is the foundation in the formation of human personality. Early childhood education should be in accordance with the needs of children in order to develop various aspects. Early childhood is an individual who continues to experience growth and development. At this time the development of the brain is so rapid that this period is also called the "golden age". In this golden period a lot of potential to be developed. The potential must be well facilitated to develop optimally. One of the facilities that can develop the potential of children is a kindergarten education institution. In this kindergarten all aspects of child development will be well developed with the stimuli that children need.

Aspects of development developed in kindergarten one of them is the social aspect. Social development is an achievement of maturity in early childhood social relations. Can also be interpreted as a learning process to adapt to group norms, morals, and traditions; merge into a communal and cooperate communion. Social development is the process of learning and behavioral skills associated with the individual to live as part of his group. In social development, children are required to have the ability to suit the social demands they are in. Social demands in question is that children can socialize well in accordance with the stage of development and age, and tend to be children who are easy to get along. At the age of kindergarten social development is indicated by the level of developmental achievement of the child can perform group tasks, can work with friends, want to play with friends, willing to lend hers, willing to share with friends, mutual help fellow friends, and patiently waiting for turn.

Based on preliminary observations in the Baiturridha Kindergarten children found the social ability of children has not developed optimally. Teachers are still less creative in creating activities in learning that are fun for children especially in choosing games in learning. With the selection of less interesting game will cause the lack of motivation of children in following the learning process. So the 
social development of children can not developc) optimally. This is indicated by the still lack of social fellow children peers.

Bredekamp and Copple (1997) suggests that early childhood education includes programs thate) serve children from birth to age eight designed to improve the intellectual, social, emotional, linguistic and physical development of children [1]. Yamin also explains that the essence of Early Childhood Education is the period of education that determines the development and future direction of a child, because education that starts from an early age will imprint well [2]. Early Childhood Education is the foundation of subsequent children's education that is full of challenges and problems. Based on the above1) opinion, Early Childhood Education is a process of developing children's development since birth.2)

Early Childhood Education aims to develop a variety of potential children from an early age in3) preparation for life and to adjust to their environment. Education of children can also be interpreted as an effort to optimize the potential of exceptional children who can be framed in education, guidance, coaching and mentoring. According to Solehuddin states that the goal of early childhood education is to facilitate the growth and development of children optimally and comprehensively in accordance with the norms and values life adopted. Through Early Childhood Education, children are expected to develop all their potential [1].

According to UNESCO ECCE (Early Childhood Care and Education) also revealed several purposes of early childhood education, among others [1], as follows:

a) Early childhood education aims to build a preliminary foundation in improving children's ability to complete higher education, lowering grade repetition and dropout rates.

b) investing human resources profitable, both for family, nation, state and religion.

c) stop the wheel of poverty

d) Early childhood education aims to participate actively in safeguarding and protecting the rights of every child to obtain education guaranteed by law.

Meanwhile, Sujiono stated that the aim of the early childhood education is to develop knowledge and understanding of parents and teachers as well as those related to early childhood education and development [3]. Specifically the objectives to be achieved are:

a) Identify early childhood physiological development and apply the identification results in the physiological development concerned.

b) Can understand the development of early childhood creativity and development-related efforts.
Can understand plural intelligence and its relation to early childhood development

d) Can understand the meaning of play for the development of early childhood

Be able to understand the learning approach and its application for the development of childhood children.

Based on the above opinion, it can be concluded that the purpose of Early Childhood Education is to develop all the abilities of children optimally so that children become a useful person for his life in the future.

According to Froebel in [4] argues that there are 3 principles that need to be considered in children's education:

The Gifts, are a number of objects that can be touched and played by children in certain ways.

The occupation, is a series of activities that give children an opportunity for artistic expression.

The mothers Play, are songs and games or games designed specifically for social activities and the child's experience of the surrounding environment.

Some principles of early childhood education that can be used by an educational institution proposed by Asmani [5]are:Child-oriented needs. Early children are children who need educational efforts to achieve optimization of all aspects of its development.Learn through play. Through child play can explore, discover, utilize and draw conclusions.Environmentally conducive environment must be created in such a way as to be interesting and fun with attention to the convenience of learning activities.Using integrated learning. Early childhood learning should use integrated learning through themes.Developing life skills. Life skills procurement can be done through the process of habituation.

1) Using various educative media and learning resources.Performed gradually and repeatedly.

Based on the above opinion it can be concluded that the principles of early childhood education are oriented to the development of children, the needs of children, developing life skills, utilizing information technology and learning should be democratic.

Play provides a way for children's social development when sharing with other children. Play is the most important means for developing social skills and expanding empathy towards others and reducing the attitude of egocentrism. Playing can grow and enhance the sense of socialization of children. Through child play can learn psosocial behaviors such as waiting turn, cooperation, mutual help, and sharing.

Traditional games are a form of game and or sporting activity that evolves from a certain community habit. In subsequent developments 
the traditional game is often used as a type of game that has characteristics of the original regional and adapted to local cultural traditions. The activities are done routinely or occasionally with the intention to seek entertainment and fill the spare time after being detached from routine activities such as working for a living, school, etc. In the execution of traditional games can incorporate elements of folk games and child games into it. It is even possible to include activities that contain elements of art such as the so-called traditional art.

Games provide various forms of activities for children which are not too serious, flexible, and the materials contained in the toys are imaginatively transformed along with the adult world.

Mayesty who explains that for children, games are their activities throughout the day. For them, games mean life and vice versa [2]. Vygotsky believes that games develop the children's cognitive directly, not just as a result of cognitive development as proposed by Piaget. Playing games is needed by younger children since it is a part of their life. Games provide pleasure for them so that they can express their feelings by playing games.

For children, playing games is a way to transform a potential force as well as a mean of channeling their energy. Jeffree, McConkey and Hewson as cited in [2] describes the general characteristics of playing games in childhood period. They are:

1) it emerges from the inner part of the children.

2) it should be free of binding rules, the activities are to be enjoyed.

3) it is a real or actual activity.

4) it should focus on the process rather than the results.

5) it should be dominated by the players.

6) it should involve the active participation of the players

1) Can develop the intellect (Cognitive) children to be able to link the knowledge that is already known to the knowledge acquired

2) Train the child's language ability to be able to communicate verbally with the environment

3) Train the children's skills in order to develop fine motor skills

4) Children to develop physical motor skills base in the body amend useful for healthy growth

5) Developing creativity of children to be creative, smooth, flexible and original. Improving children's emotional sensitivity by introducing an assortment of feelings and foster self-confidence. Develop social skills such as developing relationships with other children, with behavior in accordance with the demands of society and can adapt to a friend.
Playing provides an opportunity to take control of yourself physically. Playing expands interest and concentration of attention, Playing is the way children to investigate something, Playing is the way children learn about the role of adults, Playing is a dynamic way to learn, playing is clear consideration of the child, playing can be structured in academic. Playing is the life force, and playing is essential to the survival of humankind.

Playing has an important purpose for the growth and development of all aspects of the child both the development of cognitive, affective, physical, motor, social or religious and moral development of children. Therefore, great value plays in the lives of children, the use of play activities in the development of the character value is an absolute requirement that absolutely cann't be ignored.

\section{RESEARCH METHODS}

Based on the problems studied then this research type is quantitative with quashy experiment method (quasi experiment). Sugiyono states the method of experimental research can be interpreted as a research method used to seek the influence of certain treatment against others in controlled conditions [6]. According Sugiyonoquashy experiment with the type of nonequivalent control group design that is the type that has the experimental group or control group is not selected at random.

The population in this study is all children of Baiturriada kindergarten. Sampling technique that will be done is cluster sampling technique (sampling area). According Sugiyono[6] states cluster sampling is used to determine the sample when the object to be studied or data source is very broad. The sample in this research is group B1 and group B2 where group B1 become experiment class and class B2 become control class, with equal number of children equal.

The research instrument used in this research is the test. Researchers use teacher-made tests are tests prepared by teachers with specific procedures. The starting point of instrument preparation is the research variables that are determined to be studied, then given the indicator to be measured. The indicators are spelled out in the form of items or questions. The data analysis technique used in this study is to compare the difference of the two average values, so that it is done by $t$ test ( $t$-test), then proceed to find the size of effect (effect size) with Cohen's formula d. But before doing the $\mathrm{t}$ test (t-test), first test the normality and homogeneity test. To analyze the difference, normality test is required. While homogeneity test aims to see whether the sample class data is homogeneous or not homogeneous to test the homogeneity of the Bartlett test. If it is 
known that a normal and homogeneous distribution data is done data analysis in accordance with the analysis technique that has been done, that is by finding the comparison by using t-test.

\section{RESEARCH RESULTS}

Based on the result of social ability given in the experimental class and control class at the pretest stage, the average score of the experimental class is 61.3 and the control class average is 59 . Based on the data analysis that has been done that the tcount is 1.520 compared with 0.05 (ttable, $=2.073$ ) with degrees of freedom $\mathrm{dk}$ $(\mathrm{N} 1-1)+(\mathrm{N} 2-1)=22$. Thus thitung $<$ ttabel, ie $1.520<2.073$, then it can be said that hypothesis $\mathrm{H} 1$ rejected or $\mathrm{H} 0$ accepted. Thus, it can be concluded that there is no significant difference between children's social ability outcomes in the experimental class using traditional games with control classes using modern games.

Based on the results of numeracy ability given in the experimental class and control class at the post-test stage obtained the average rate of the experimental class is 89 and the average number of control classes is 69 . Based on the results of data analysis has done that $t$ count of 9.037 compared with 0.05 (ttable, $=2.073$ ) with degrees of freedom dk $(\mathrm{N} 1-1)+(\mathrm{N} 2-1)=22$. Thus thitung $>$ ttable, ie $9.037>2.073$, then it can be said that hypothesis $\mathrm{H} 1$ accepted or $\mathrm{H} 0$ rejected. Thus, it can be concluded that the development of children's social skills in the experimental class using traditional games is more effective than the control class that uses the modern game. This is because traditional games have advantages over modern games, that is, traditional games help children to improve their ability to cooperate with their friends and help their children to obey the rules especially in playing. In contrast to modern games that more form the child to live individually and not able to problems solving in playing.

\section{CONCLUSIONS}

Based on the results of data analysis that has been done, it can be concluded that there are differences in social ability of children in kindergarten Baiturridha, Padang Pariaman, significant between experiment class (B1) and control class (B2). This proves that traditional games are effective against children's social skills, so the average value obtained from the experimental class is higher (89) than the control class (69).

This can be seen from the result of hypothesis test that thitung $>$ ttabel, that is $9,037>2,073$, hence can be concluded that development of social ability of children in experimental class using traditional game more effective than control class using modern game.

\section{ACKNOWLEDGEMENTS}

Thank you very much forUniversitasNegeri Padang dan Majoring in teacher education for early childhood education.

\section{References}

[1] Suyadi dan Maulidya Ulfah. KonsepDasar PAUD. Bandung: PT Remaja Rosdakarya. 2013

[2] Yamin Martinis dan Jamila SabriSanan. Panduan PAUD. Jakarta :Referensi. 2013

[3] Sujiono, Yuliani Nurani. Konsep Dasar Pendidikan Anak Usia Dini. Jakarta: PT Indeks. 2009

[4] Suryana, Dadan. PendidikanAnakUsiaDini. Padang: UNP Press. 2013

[5] Asmani, Jamal Ma'mur. Manajemen Strategis Pendidikan Anak Usia Dini. Jogjakarta: DIVA Press. 2009

[6] Sugiyono. Metode Penelitian Pendidikan. Bandung: Alfabeta. 2012. 